\title{
ELIMINASI BAKTERI Escherichia coli O157:H7 DAN Escherichia coli O157 PADA DAGING SAPI MENGGUNAKAN SINAR ULTRAVIOLET
}

\section{ELIMINATION OF Escherichia coli O157:H7 AND Escherichia coli O157 ON MEAT BY ULTRAVIOLET IRRADIATION}

\author{
Revi Juniar Nutrihidayah ${ }^{1}$, Retno Kawuri², Inna Narayani ${ }^{2}$ \\ ${ }^{1}$ Program Studi Biologi Fakultas Matematika dan Ilmu Pengetahuan Alam \\ ${ }^{2}$ Program Studi Biologi Fakultas Matematika dan Ilmu Pengetahuan Alam \\ Universitas Udayana \\ Bukit Jimbaran \\ Email : revijuniar22@gmail.com
}

\section{ABSTRAK}

Infeksi menjadi masalah utama angka kematian dan kesakitan di dunia, salah satu faktor infeksi pada saluran pencernaan yaitu bakteri. Strain Escherichia coli $\mathrm{O} 157$ dan Escherichia coli O157:H7 adalah bakteri penyebab diare berdarah hingga kematian. Sinar ultraviolet memiliki potensi dalam eliminasi bakteri. Tujuan penelitian ini untuk mengetahui bagaimana dekontaminasi E. coli $\mathrm{O} 157$ dan E. coli $\mathrm{O} 157: \mathrm{H} 7$ pada daging sapi setelah penyinaran ultraviolet. Metode RAK faktorial dua faktor yaitu jarak $(5,10,15$, dan $20 \mathrm{~cm})$ dan waktu (5, 10, 15, 20, dan 25 menit) diulang sebanyak dua kali sehingga didapatkan 80 sampel. Data kuantitatif dianalisis menggunakan analysis univariant dilanjutkan uji Least Significant Difference signifikan 5\%. Penyinaran terdekat E. coli $\mathrm{O} 157$ pada daging dengan jarak $5 \mathrm{~cm}$ selama 25 menit menunjukkan penurunan yang signifikan $(88,62 \%)$, sedangkan jarak terjauh $20 \mathrm{~cm}$ selama 25 menit menurun $(73,42 \%)$. Penyinaran terdekat E. coli $0157:$ H7 pada daging dengan jarak $5 \mathrm{~cm}$ selama 25 menit menunjukkan penurunan (86,78\%), sedangkan jarak terjauh $20 \mathrm{~cm}$ selama 25 menit $(75,16 \%)$, terjadi kenaikan jumlah koloni pada beberapa variasi perlakuan tetapi secara keseluruhan menurun. Kesimpulan terjadi penurunan jumlah koloni bakteri yang signifikan pada daging yang diberikan kultur E. coli O157 sedangkan terjadi penurunan jumlah koloni yang fluktuatif pada daging yang diberi kultur E. coli O157:H7.

Kata Kunci: bakteri patogen, diare, eliminasi, ultraviolet

\begin{abstract}
Infection is a major problem mortality and morbidity in the world, a lot of an infection in the digestive tract is causes bacteria. The Escherichia coli $\mathrm{O} 157$ and Escherichia coli $\mathrm{O} 157$ : H7 strains are bacteria that cause bloody diarrhea to death. Ultraviolet light has the potential to eliminate bacteria. The purpose is to know decontamination of E. coli $\mathrm{O} 157$ and E. coli O157: $\mathrm{H} 7$ on meat after ultraviolet exposure. The method is a factorial RBD with two factors (distance and time) with variations in distances $(5,10,15$, and $20 \mathrm{~cm})$ and times $(5,10,15,20$ dan 25 minutes). All treatments were repeated twice and obtained 80 samples. The quantitative data obtained were using univariant analysis followed by the Least Significant Difference with a significant level of 5\%. The irradiation for E. coli $\mathrm{O} 157$ on meat with $5 \mathrm{~cm}$ for 25 minutes showed a significant reduction $(88,62 \%)$, while the farthest distance $20 \mathrm{~cm}$ for 25 minutes decreased $(73,42 \%)$. The nearest irradiation $E$. coli $\mathrm{O} 157$ : $\mathrm{H} 7$ on meat $5 \mathrm{~cm}$ for 25 minutes show decrease $(86,78 \%)$, while the farthest distance was $20 \mathrm{~cm}$ for 25 minutes $(75,16 \%)$, there was an increase colonies in several treatment variations but overall decreased. In conclusion there was significant decrease number of bacterial colonies in meat given E. coli $\mathrm{O} 157$ culture, while there was a fluctuation decrease number of colonies in meats given E. coli O157: $\mathrm{H} 7$ culture.
\end{abstract}

Keywords: diarrhea, elimination, pathogenic bacteria, ultraviolet 


\section{PENDAHULUAN}

Infeksi menjadi masalah utama bagi manusia karena dapat menyebar dengan mudah. Penyebaran infeksi dapat melalui manusia atau hewan sebagai perantara (Putri, 2010). Angka kematian akibat infeksi saluran pencernaan atau diare beberapa tahun terakhir terpantau tinggi. Tercatat tahun 2017 diare menjadi kategori KLB (kejadian luar biasa) dalam lima tahun terakhir mencapai 1.725 jiwa (Kemenkes RI, 2018). Data kasus dunia menunjukkan infeksi saluran pencernaan menewaskan 3,5 juta jiwa (WHO, 2014).

Foodborne disease merupakan infeksi yang disebabkan oleh minuman atau makanan tercemar. Makanan yang berasal dari tumbuhan serta hewan dapat berperan sebagai medium perantara penyebab penyakit pada manusia, umumnya bersifat toksik dan menyebabkan infeksi (WHO, 2014). Foodborne disease terjadi akibat kontaminasi patogen yang tumbuh dan berkembang selama penyimpanan maupun saat proses pembuatan (BPOM, 2008).

Beberapa jenis E. coli penyebab penyakit yang mengeluarkan toksin. Toksin tersebut dikenal dengan Shiga-like toxin (Rahal et al., 2015). Salah satu jenis yang teridentifikasi adalah E. coli O157:H7, gejala yang ditimbulkan jika seseorang terinfeksi yaitu kejang otot perut, diare selama 24 jam (Rananda dkk., 2016). Jika tidak segera diatasi dapat menyebabkan hemolytic uremic syndrome (HUS) pada manusia dan hermorrhagic colitis (HC) (Suardana dkk., 2007).

Kontaminasi melalui produk pangan berpeluang menyebarkan infeksi. Kebanyakan E. coli O157:H7 ditemukan saat proses pengolahan daging yang belum matang (Doyle et al., 2006). Sampel daging dari rumah potong hewan di pasar tradisional Denpasar, Badung dan
Klungkung positif E. coli O157:H7 sebesar 25,6\% (Purniwirathi, 2019). Persentase kontaminasi E. coli O157:H7 sebesar 70\% di rumah potong hewan di Lubuk Buaya Padang (Rananda dkk., 2016).

Praktik pengolahan yang buruk, kebersihan alat, serta sanitasi lingkungan yang tidak diperhatikan menyebabkan $E$. coli O157:H7 mencemari produk pangan. Diperlukan upaya dalam mengendalikan cemaran patogen pada produk pangan. Sterilisasi merupakan metode menghilangkan mikroorganisme beserta spora yang tidak dikehendaki (Nurhikmat dkk., 2016). Salah satu metode sterilisasi yaitu penyinaran ultraviolet yang memiliki keuntungan antara lain aman bagi lingkungan dan tidak mengeluarkan residu (Clordysis, 2019).

Penggunaan sinar ultraviolet dikategorikan mampu menonaktifkan patogen bawaan makanan dengan sinar ultraviolet C (Shin et al., 2016). Menurut Kawuri (1986), pelemahan bakteri dapat dilakukan dengan penyinaran sinar gamma dan sinar ultraviolet. Menurut Kim et al. (2016) sinar ultraviolet memiliki potensi dalam menurunkan patogen bawaan pada produk makanan tanpa mempengaruhi rasa, warna dan kualitas. Sejalan dengan penelitian Nerandzic et al. (2012) sinar ultraviolet efektif membunuh spora mikroorganisme. Menurut Yang et al. (2017) jarak dan waktu tertentu memiliki kemampuan yang efektif dalam mengurangi bakteri patogen. Menurut Mukhopadhyay et al. (2014) lokasi patogen yang spesifik pada bagian permukaan produk mempengaruhi efektivitas penyinaran ultraviolet.

Dengan demikian perlu dilakukan penelitian untuk mengetahui kemampuan sinar ultraviolet sebagai eliminator mikroorganisme pada daging sapi yang 
diberikan kultur E. coli O157 dan E. coli O157:H7.

\section{METODE PENELITIAN}

\section{Waktu dan tempat penelitian}

Dilaksanakan di Lab. Mikrobiologi Prodi Biologi FMIPA Bukit Jimbaran Bali. Dimulai pada bulan Desember 2019 sampai dengan bulan September 2020.

\section{Variabel Penelitian}

Variabel kontrol jenis bakteri ( $E$. coli O157:H7 dan E. coli O157), suhu inkubasi bakteri $\left(37^{\circ} \mathrm{C}\right)$, media bakteri Eosin Methylene Blue Agar (EMBA merk Oxoid), daging sapi bagian sirloin sebanyak 10 gram atau sebanding dengan (4 x 4 x $1 \mathrm{~cm})$. Variabel bebas yaitu panjang gelombang ultraviolet $(249,44 \mathrm{~nm})$, jarak $(5,10,15$, dan $20 \mathrm{~cm})$, waktu $(5,10,15,20$, dan 25 menit). Total koloni bakteri merupakan variabel terikat.

\section{Rancangan Penelitian}

Rancangan penelitian yaitu rancangan acak kelompok dua faktor variasi (jarak penyinaran dan waktu penyinaran) dengan dua kali ulangan, sehingga didapatkan 80 sampel.

\section{Preparasi dan uji konfirmasi bakteri $\boldsymbol{E}$. coli 0157 dan $E$. coli $0157: H 7$}

Kultur bakteri E. coli $\mathrm{O} 157$ dan E. coli O157:H7 (koleksi Balai Laboratorium Kesehatan Provinsi Bali) direkultur pada media EMBA selanjutnya dibiakkan pada media $N B$ atau Nutrient Broth selanjutnya diinkubasi suhu $37^{\circ} \mathrm{C}, 24$ jam.

Uji konfirmasi kedua kultur dilakukan di Balai Labkes Prov. Bali. Hal ini berfungsi untuk memastikan dan membedakan koloni E. coli $\mathrm{O} 157$ \& E. coli non O157. Jika terlihat koloni tidak berwarna (colourless) pada Sorbitol MacConkey Agar (SMAC), maka koloni E. coli tersebut adalah E. coli O157, dikarenakan tidak memfermentasi sorbitol. Uji konfirmasi E. coli O157 dilakukan menggunakan uji reagen latex (Microgen), Jika terdapat aglutinasi dalam uji latex maka benar kultur tersebut adalah $E$. coli O157.

Uji konfirmasi dilanjutkan untuk menentukan E. coli O157:H7 menggunakan uji serologis H7. Koloni yang dicurigai $E$. coli $\mathrm{O} 157: \mathrm{H} 7$ pada media Sorbitol MacConkay Agar dikulturkan pada Sulfide Indol Motility (SIM). Jika terdapat warna putih berkabut disekitar daerah tusukan pada media SIM maka koloni tersebut positif E. coli O157:H7. Bakteri yang menunjukkan hasil positif pada uji motility diinokulasi pada media $\mathrm{BHI}$ atau Brain Heart Infusion dan diinkubasi dengan suhu $37^{\circ} \mathrm{C}, 24$ jam. Isolat pada $B H I$ selanjutnya diinaktivasi menggunakan larutan $\mathrm{NaCl} 1 \%$ dengan perbandingan 2 ose (loop) inokulum E. coli $\mathrm{O} 157: \mathrm{H} 7$ pada media $B H I$ ke dalam $2 \mathrm{~mL}$ larutan $\mathrm{NaCl} 1 \%$ kemudian dipanaskan $40-50^{\circ} \mathrm{C}$ dalam waterbath selama 6 jam. Sebanyak $50 \mu \mathrm{L}$ antigen dan $50 \mu \mathrm{L}$ antiserum $\mathrm{H} 7$ dimasukkan ke dalam microplate. Butiran pasir pada dasar microplate menandakan bakteri tersebut positif E. coli O157:H7 (Microgen, 2012).

\section{Preparasi dan inokulasi sampel}

Sebelum menentukan jumlah koloni awal pengenceran, kultur bakteri ditanam terlebih dahulu dan disamakan dengan standar kekeruhan McFarland 0,5\%. Kultur yang telah diinkubasi diambil $1 \mathrm{~mL}$ dan dimasukkan kedalam $9 \mathrm{~mL}$ Peptone Water pada tabung reaksi dan dilakukan pengenceran hingga $10^{4}$.

\section{Penyinaran sinar UV pada daging sapi} yang diinokulasi $E$. coli 0157 dan $E$. coli O157:H7 
Kultur yang telah disiapkan diambil $1 \mathrm{~mL}$ dan dioleskan menggunakan hockey stick pada permukaan daging bebas E. coli O157:H7 dan E. coli O157 dengan ukuran $4 \times 4 \times 1 \mathrm{~cm}$ atau sebanding 10 gram. Daging diberi perlakuan waktu pemaparan sinar ultraviolet selama 5, 10, 15, 20, 25 menit dengan jarak 5, 10, 15, $20 \mathrm{~cm}$ dan kontrol (tanpa penyinaran) dengan dua kali ulangan. Daging yang telah diberikan perlakuan selanjutnya dicacah secara aseptik dan dimasukkan ke dalam botol steril $90 \mathrm{~mL}$ media $P W$, divortex sehingga didapatkan hasil yang homogen. Dilakukan seri pengenceran hingga $10^{4}$ dan ditanam pada EMBA, selanjutnya diinkubasi 24 jam, $37^{\circ} \mathrm{C}$ (Kim et al., 2016).

\section{Analisis data}

Hasil ditampilkan deskriptif dengan gambar dan grafik, dianalisa menggunakan analisis univariant taraf signifikan 5\%. Jika hasil berbeda secara nyata, dilanjutkan uji Least Significant Difference, aplikasi SPSS Statistics 23.

\section{HASIL DAN PEMBAHASAN}

\section{Hasil analisis penyinaran UV E. coli 0157 dengan daging sapi}

Penyinaran ultraviolet terhadap daging yang diberikan kultur E. coli $\mathrm{O} 157$ menunjukkan penurunan yang signifikan jika di bandingkan dengan angka kontrol $6,02 \times 10^{6} \mathrm{CFU} / \mathrm{g}$ (Gambar 1). Penyinaran selama 5 menit dengan jarak 5, 10, 15 dan $20 \mathrm{~cm}$ penurunan jumlah koloni yaitu (76,74\%), (63,29\%), (57,56) dan $(40,20 \%)$ koloni. Penyinaran 10 menit dengan jarak 5, 10, 15 dan $20 \mathrm{~cm}$ menurun $(80,32 \%)$, (68,19\%), (66,45\%) dan (60,13\%) koloni. Penyinaran selama 15 menit dengan jarak $5,10,15$ dan $20 \mathrm{~cm}$ menurunkan koloni $(84,97 \%), \quad(70,68 \%), \quad(67,94 \%)$ dan $(63,12 \%)$. Penyinaran selama 20 menit dengan jarak $5,10,15$ dan $20 \mathrm{~cm}$ yaitu $(86,88 \%), \quad(74,42 \%), \quad(73,17 \%)$ dan $(68,11 \%)$ koloni bakteri. Penyinaran selama 25 menit dengan jarak 5, 10, 15 dan $20 \mathrm{~cm}$ yaitu $(88,62 \%),(81,89 \%),(76,91 \%)$ dan $(73,42 \%)$ koloni bakteri. Semakin lama penyinaran ultraviolet dengan kombinasi jarak yang semakin dekat, jumlah koloni bakteri semakin berkurang (Tabel 1).

Tabel 1. Persentase penurunan populasi E. coli O157 pada daging sapi setelah penyinaran UV kombinasi jarak dan waktu

\begin{tabular}{ccccc}
\hline \multicolumn{5}{c}{$(\%)$} \\
\hline $\begin{array}{c}\text { Waktu } \\
\text { penyinaran } \\
\text { (menit) }\end{array}$ & 5 & 10 & 15 & 20 \\
\cline { 2 - 5 } & $56,74 \pm 1,8^{\mathrm{ijkl}}$ & $63,29 \pm 0,7^{\mathrm{bc}}$ & $57,56 \pm 2,0^{\mathrm{b}}$ & $40,20 \pm 8,4^{\mathrm{a}}$ \\
5 & $80,32 \pm 1,5^{\mathrm{klm}}$ & $68,19 \pm 2,4^{\mathrm{cg}}$ & $66,45 \pm 2,3^{\text {cd }}$ & $60,13 \pm 2,8^{\mathrm{b}}$ \\
10 & $84,97 \pm 0,3^{\mathrm{mno}}$ & $70,68 \pm 1,0^{\mathrm{defgh}}$ & $67,94 \pm 4,4^{\mathrm{ce}}$ & $63,12 \pm 0,4^{\mathrm{bc}}$ \\
15 & $86,88 \pm 1,8^{\text {no }}$ & $74,42 \pm 2,3^{\mathrm{hijk}}$ & $73,17 \pm 1,0^{\text {cf }}$ & $68,11 \pm 3,7^{\text {cf }}$ \\
20 & $88,62 \pm 2,0^{\circ}$ & $81,89 \pm 3,9^{\mathrm{lmn}}$ & $76,91 \pm 0,4^{\mathrm{ijkl}}$ & $73,42 \pm 0,9^{\text {efgj }}$ \\
25 & &
\end{tabular}

Keterangan : Nilai Tabel $1 \pm$ standar deviasi yaitu persentase rerata dua ulangan. Huruf yang sama pada nilai-nilai diatas menujukkan rerata yang tidak memiliki perbedaan nyata $(\mathrm{p}>0,05)$ berdasar uji Least Sig. Difference (LSD), setelah dilakukan analisis Univariate. 
Berikut merupakan kontrol E. coli $\mathrm{O} 157$ pada daging sapi dikultur dalam EMBA (Gambar 1).
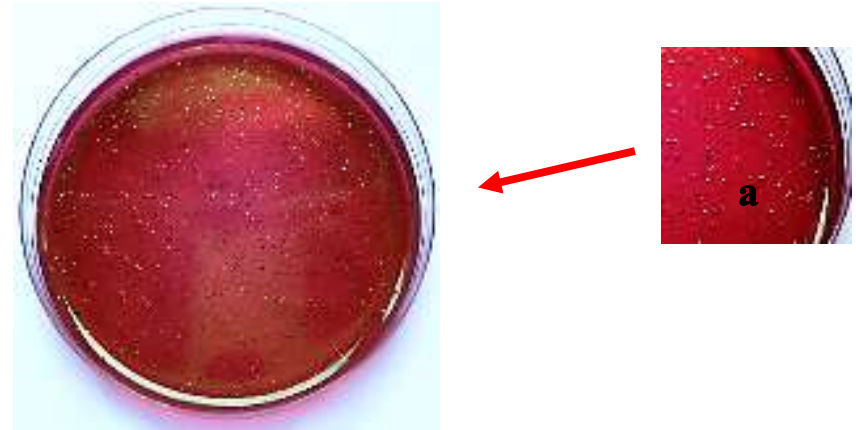

Gambar 1. Kontrol E. coli O157 pada daging sapi yang dikultur di EMBA koloni bakteri berwarna hijau metalik)

Tabel 2. Persentase penurunan populasi E. coli $\mathrm{O} 157: \mathrm{H} 7$ pada daging sapi setelah penyinaran UV kombinasi jarak dan waktu

\begin{tabular}{ccccc}
\hline \multicolumn{4}{c}{$(\%)$} \\
\hline $\begin{array}{c}\text { Waktu } \\
\text { penyinaran } \\
\text { (menit) }\end{array}$ & 5 & 10 & 15 & 20 \\
\cline { 2 - 5 } & $74,52 \pm 0,9^{\text {de }}$ & $50,24 \pm 3,4^{\text {a }}$ & $40,76 \pm 13,0^{\text {a }}$ & $44,59 \pm 3,6^{\text {a }}$ \\
5 & $78,90 \pm 1,9^{\text {defg }}$ & $58,92 \pm 2,2^{\text {bc }}$ & $61,46 \pm 2,7^{\text {bc }}$ & $61,78 \pm 3,1^{\text {bc }}$ \\
10 & $83,04 \pm 2,1^{\text {defg }}$ & $67,04 \pm 2,2^{\text {bcde }}$ & $68,47 \pm 2,7^{\text {bcde }}$ & $64,65 \pm 2,7^{\text {bcde }}$ \\
15 & $86,15 \pm 1,1^{\text {fg }}$ & $66,56 \pm 1,3^{\text {bcde }}$ & $68,79 \pm 1,8^{\text {bcde }}$ & $76,11 \pm 4,0^{\text {de }}$ \\
20 & $86,78 \pm 1,1^{\text {fg }}$ & $70,62 \pm 3,7^{\text {bcde }}$ & $66,72 \pm 3,3^{\text {bcde }}$ & $75,16 \pm 4,0^{\text {de }}$ \\
25 & & & &
\end{tabular}

Keterangan : Nilai Tabel $2 \pm$ standar deviasi yaitu persentase rerata dua ulangan. Huruf yang sama pada nilai-nilai diatas menujukkan rerata yang tidak memiliki perbedaan nyata $(p>0,05)$ berdasar uji Least Sig. Difference (LSD), setelah dilakukan analisis Univariate.

Berikut merupakan kontrol E. coli $\mathrm{O} 157$ pada daging sapi dikultur dalam EMBA (Gambar 2).

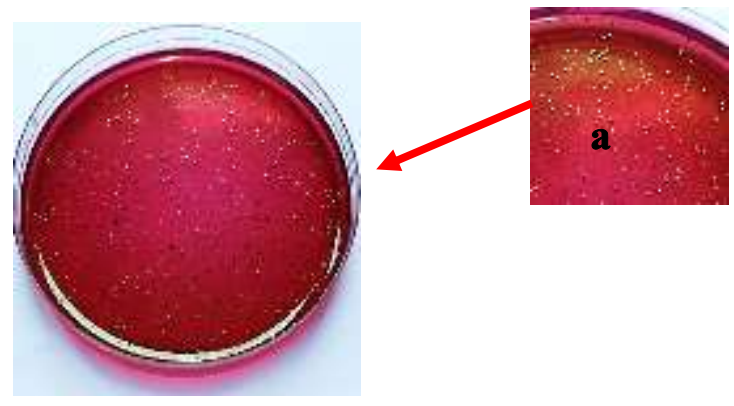

Gambar 2. Kontrol E. coli O157:H7 pada daging sapi yang dikultur di EMBA (a. koloni bakteri berwarna hijau metalik) 


\section{Pembahasan}

Pengaruh penyinaran ultraviolet pada daging sapi yang diberikan kultur $E$. coli $\mathrm{O} 157$ menunjukkan penurunan jumlah koloni yang signifikan jika dibandingkan dengan kontrol, terlihat antar kelompok penyinaran tidak menujukkan perbedaan yang nyata (Tabel 1). Sedangkan penyinaran ultraviolet pada daging sapi yang diberikan kultur E. coli O157:H7 menunjukkan penurunan yang fluktuatif pada beberapa variasi jarak $(10 \mathrm{~cm}, 15 \mathrm{~cm}$, $20 \mathrm{~cm}$ ) dapat dilihat pada Tabel 2 .

Hasil penyinaran ultraviolet $E$. coli O157 dan E. coli O157:H7 menggunakan variasi jarak dan waktu menunjukkan penurunan jumlah koloni yang signifikan ( $p$ $<0,05)$ dengan kontrol. Hasil penyinaran ultraviolet pada E. coli $\mathrm{O} 175$ dan E. coli O157:H7 menunjukkan penurunan jumlah koloni bakteri sejalan dengan penambahan lama waktu penyinaran. Hasil uji statistika analisys univariate yang dilanjutkan dengan uji LSD (Least Significant Different) atau uji beda nyata paling kecil menunjukkan nilai $\mathrm{p}<0,05$ artinya jarak dan waktu berpengaruh terhadap penurunan jumlah koloni bakteri.

$\begin{array}{ccrr}\text { Hasan } & \text { dan } & \text { Dzakaria } & \text { (2013) } \\ \text { menyatakan } & \text { sinar } & \text { radiasi } & \text { dapat }\end{array}$
menyebabkan sel rusak hingga ke bagian DNA. Kerusakan DNA dapat mengakibatkan kematian sel meskipun dalam jumlah sedikit. Eksitasi dan ionisasi menyebabkan kerusakan secara langsung maupun tidak langsung terhadap susunan DNA. Menurut Pelczar and Chan (2014) sinar ultraviolet banyak diserap oleh bahan seluler, tetapi paling banyak adalah asam nukleat sehingga menimbulkan banyak kerusakan.

Radiasi ultraviolet merupakan energi yang memiliki kemampuan daya tembus pada dinding sel mikroorganisme. Mekanisme paparan sinar ultraviolet pertama-tama energi tersebut di serap asam nukleat adanya kerusakan pada permukaan sel, penyerapan energi kemudian merubah susunanan ikatan antara molekul-molekul timin yang bersebelahan, akhirnya fragmen timin terbentuk (Timin dimer), hal tersebut mengakibatkan ekspresi asam nukleat terganggu dan mikroorganisme tidak mampu bereplikasi (Ariyadi dan Dewi, 2009). Kerusakan lain yang dapat muncul akibat penyinaran ultraviolet pada mikroorganisme yaitu crosslink DNA atau kehilangan basa DNA, terputusnya rantai ganda DNA atau double strand breaks (DSB), dan terputusnya rantai tunggal DNA atau single strand breaks (SSB) (Cutler and Zimmerman, 2011). Beberapa kerusakan DNA dapat diperbaiki, tetapi juga memiliki peluang kegagalan sehingga dapat mengakibatkan kematian sel (Hasan dan Dzakaria, 2013).

Sinar ultraviolet efektif menyinari mikroorganisme bagian permukaan. Sejalan pernyataan tersebut, suspensi yang tersinari hanya pada bagian permukaan daging sapi, tidak sampai pada bagian dalam. Hal tersebut menyebabkan bakteri tidak dapat tereliminasi secara keseluruhan (Pelczar and Chan, 2005).

Faktor lain yang dapat mempengaruhi penyinaran ultraviolet adalah komponen daging dan aktivitas air. Menurut Soeparno (2009) komponen penyusun daging diantaranya jaringan saraf, jaringan epitel, jaringan ikat, lemak dan pembuluh darah. Menurut Buckle et al. (2007) daging tersusun dari komposisi kimia yang terdiri dari $75 \%$ air, $18,5 \%$ protein dan $3 \%$ lemak. Persentase air paling banyak dibandingkan dengan unsur kimia 
lainnya. Sejalan dengan hal tersebut menurut Sulatri dkk. (2017) aktivitas air merupakan jumlah air bebas yang terkandung dalam pangan, sehingga dipergunakan mikroorganisme untuk tumbuh.

Menurut Supriyatin dan Prambudi (2020) daging has luar atau sirloin memiliki persentase lemak sebesar 13,79\%-14,72\% yang lebih kecil jika dibandingkan dengan bagian has dalam atau terderloin 15,04\% $16,02 \%$, kadar lemak yang lebih rendah pada sirloin disebabkan oleh aktivitas otot pectoralis yang sering digunakan untuk bekerja. Pemilihan jenis daging rendah lemak digunakan untuk memperkecil adanya peluang celah daging yang berbeda. Menurut Campbell et al. (2010) jaringan otot tersusun dari banyaknya rongga. Hal ini memungkinkan mikroorganisme masuk pada celah daging sehingga sinar ultraviolet tidak dapat menembus bagian dalam.

Penurunan jumlah koloni bakteri terhadap efektivitas sinar ultraviolet dipengaruhi beberapa hal diantaranya intensitas cahaya yang digunakan, jarak penyinaran, luas ruangan, lama penyinaran, jenis bakteri (Sulatri dkk., 2017), dan panjang gelombang (Vermeulen et al., 2008).

\section{KESIMPULAN}

Dekontaminasi daging sapi yang diberikan E. coli O157 mengalami penurunan yang signifikan pada jumlah koloni bakteri, sedangkan daging sapi yang diberikan E. coli O157:H7 memperlihatkan penurunan jumlah koloni yang fluktuatif. Terdapat beberapa faktor yang mempengaruhi penurunan jumlah bakteri diantaranya jenis bakteri, jarak sumber cahaya, dan lama penyinaran.

\section{SARAN}

Perlu dilakukan penelitian lanjutan menggunakan panjang gelombang sinar ultraviolet berbeda dan variasi jenis bakteri, sehingga mendapatkan hasil yang lebih baik sebagai referensi preventif kontaminasi bakteri patogen pada makanan.

\section{UCAPAN TERIMA KASIH}

Terimakasih kepada Yan Ramona, Ni Wayan Sudatri dan Dwi Ariani Yulihastuti atas saran dan masukannya selama pembuatan artikel ini.

\section{DAFTAR PUSTAKA}

Ariyadi, T dan S. S. Dewi. 2009. Pengaruh Sinar Ultraviolet terhadap Pertumbuhan Bakteri Bacillus sp. sebagai Bakteri Kontaminan. Jurnal Ilmu Kesehatan. 2(2): 20-25.

BPOM. 2008. Informatorium Obat Nasional Indonesia, Badan Pengawas Obat \& Makanan RI. BPOM Press. Jakarta.

Buckle, K. A., R. A. Edwards, G. H. Fleet dan M.

Wootton. 2007. Ilmu Pangan. UI. Jakarta.

Campbell, N. A., J. B. Reece, E. J. Simon, J. L.

Dickey, dan K. A. Hogan. 2010. Biologi. Edisi 8 Jilid 3 Terj: Damaring Tyas. Erlangga. Jakarta.

Clordysis. 2019. UV Light Disinfection Data Sheet, application note\#12, Rev. 5. Clordysis Solutions, Inc. Branchburg, Lebanon.

Cutler, T. D., and J. J. Zimmerman. 2011. UV Irradiation \& The Mechanisms Underlying It's In-activation of Infectious Agents. Animal Health Respiratory. 12:15-23.

Doyle, M. E., J. Archer, C. W. Kaspar, and R. Weiss. 2006. Human Illness E. coli O157:H7 from Food \& Non food Source. Food Research 
Institute. USA.

Hasan, I., dan H. M. Dzakaria. 2013.

Kematian Sel akibat Radiasi. Journal of The Indonesian Radiation Oncology Society. 4 (2): 1-7.

Kawuri, R. 1986. Pengukuran Titer Antiserum dari Itik yang divaksinasi dengan Vaksin Hidup Salmonella typhimurium $\mathrm{Z}_{12}$ yang disinari dengan Ultraviolet (Skripsi). UNPAD, Bandung.

Kementrian Kesehatan RI. 2018. Profil Kesehatan Indonesia 2017. Kemenkes RI. Jakarta.

Kim, S.-J., D. K. Kim, and D. H. Kang. 2016. Using UVC LED at Wavelengths of 266 to $279 \mathrm{~nm}$ to Inactivate Foodborne Pathogens \& Pasteurize Sliced Cheese. Applied and Environmental Microbiology. 82(1): 11-17.

Nerandzic, M. M., J. L. Cadnum, K. E. Eckart, and C. J. Donskey. 2012. Evaluation of Hand Held Far UV Radiation Device for Decontamination of Clostridium difficile \& other Healthcare associated Pathogens. BMC Infectious Diseases. 12(1): 1-6.

Microgen. 2012. Escherichia coli Antisera. Microgen Bioproduct Limited. UK. Mukhopadhyay, S., D. O. Ukuku, V. Juneja, and X. Fan. 2014. Effects of UV-C treatment In-activation of Salmonella enterica \& Escherichia coli $\mathrm{O} 157: \mathrm{H} 7$ on Grape Tomato Surface \& Stem Scars, Microbial Loads, and Quality. J. Food Control. 44(1): 110-117.

Nurhikmat, A., B. Suratmo, N. Bintoro, dan S. Suharwadji. 2016. Pengaruh Suhu \& Waktu Sterilisasi terhadap Nilai F \& Kondisi Fisik Kaleng Kemasan pada Pengalengan Gudeg. Jurnal Agritech. 36 (1) : 71-78.

Purniwirathi, N. W. 2019. Eliminasi Escherichia coli $\mathrm{O} 157: \mathrm{H} 7$ diisolasi Dari Daging Sapi Yang Diperdagangkan di Bali. (Thesis).
Program Pascasarjana, Universitas Udayana, Bali.

Pelczar, M. J. dan E. C. S. Chan. 2014. Dasar- dasar Mikrobiologi (terjemahan Indonesia). UI. Jakarta.

Putri, Z. F. 2010. Uji Aktivitas Antibakteri EkstrakEtanol Daun Sirih (Piper betle L.) terhadap Propionibacterium acne \& Staphylococcus aureus multiresisten. (Skripsi). Fakultas Farmasi Universitas Muhammadiyah, Surakarta.

Rahal, E. A., S. M. Fadlallah, F. J. Nassar, N. Kazzi, and G. M. Matar. 2015. Approaches to Treatment of Emerging Shiga toxin-Producing Escherichia coli Infections High Lighting the O104:H4 Serotype. Frontiers in Cellular\&Infection Microbiology.25(1):1-9.

Rananda, R. M., A. Djamal, dan Julizar. 2016. Identifikasi Bakteri Escherichia coli O157:H7 dalam Daging Sapi yang Berasal dari Rumah Potong Hewan Lubuk Buaya. Jurnal Kesehatan Andalas. 5(3) : 614-618.

Shin, J. Y., S. J. Kim, D. Y. Kim, and D. H. Kang. $\quad 2016 . \quad$ Fundamental Characteristic of Deep UV LED \& their Application to Control Foodborne Pathogens. Applied and Environmental Microbiology. 82(1):1-10.

Soeparno. 2009. Ilmu dan Teknologi Daging. Gadjah Mada University Press. Yogyakarta.

Suardana, I. W., B. Sumiarto, dan D. W. Lukman. 2007. Isolasi \& Identifikasi Escherichia coli O157:H7 pada Daging Sapi di Kab. Badung Provinsi Bali. Jurnal Veteriner. 8(1):16-23.

Sulatri, N. L., I. B. A. Yogeswara, dan N. W. Nursini. 2017. Efektifitas Sinar UV terhadap Cemaran Bakteri Patogen pada Makanan Cair Sonde untuk Pasien Immunecompromised. Jurnal Gizi 
Indonesia. 5(2): 112-118.

Supriyatin dan H. Prambudi. 2020. Kajian

Kualitas Kimia Daging Sapi

Tenderloin \& Sirloin di RPH

Tradisional di Kab. Cirebon. Jurnal

Health Sains. 1 (3): 169-177.

Vermeulen, N., W. J. Keeler, K.

Nandakumar, and K. T. Leung. 2008. The Bactericidal Effect of UV \& Visible Light on Escherichia coli. Biotechnology and Bioengineering. 99 (3): 550-556.

Yang, J., U. Wu, H. Tai and W. Sheng. 2017. Effectiveness of an UVC Disinfection System for Reduction of Healthcare Associated Pathogens. Journal of Microbiology, Immunology and Infection. 52 (1) : 487-493.

World Health Organization (WHO). 2014. Infection Prevention and Control of Epidemic and Pandemic Prone Acute Respiratory Infections in Health Care. WHO Press. Switzerland. 